\title{
Indonesia, the Cold War and Non-Alignment: Relations of the Early Indonesian Cabinets with the United States, 1950-52*
}

\author{
Richard Mason
}

\begin{abstract}
Indonesia, the Cold War and Non-alignment: Relations of the Early Indonesian Cabinets with the United States, 1950-1952.

The Cold War initially focused on Europe but promptly spread to encompass the entire globe. By the early 1950s, the Cold War belligerents began to compete for the allegiance of the newly independent nations. Many of the newly independent nations, however, had from the outset, preferred not to choose sides in the Cold War. India, Burma and Indonesia had all purported to pursue a policy of neutralism and non-alignment in the Cold War. This paper discusses the attempts of the newly independent Republic of Indonesia to steer a policy of nonalignment in the Cold War and the challenges thereto posed by the United States' Cold War policies during the early 1950s. It traces the experiences of the Hatta, Natsir and Sukiman cabinets, 1950-1952. The central theme of the paper is the interplay between the Indonesian policy of non-alignment in the Cold War and the US policy of containment. The paper argues that despite their profession to non-alignment, the early Indonesian cabinets had leaned towards the United States. Indonesia fell with the Anglo-American economic and military orbit. Desirous of American aid, Indonesia increasingly compromised on its stance of nonalignment in the Cold War. The dilemma of dependence proved to be a major stumbling block in Indonesia's attempt to pursue non-alignment.
\end{abstract}

Key words: United States, Cold War, Containment, Non-alignment, Indonesia 


\section{Introduction}

The Cold War was a term coined to describe the state of the relations between the United States and the Soviet Union after the end of the Second World War. Unable to agree over a host of postwar issues, the wartime alliance between the United States and the Soviet Union broke down irreparably. Initially focused on Europe, the Soviet-American antagonism promptly spread to engulf the entire globe. By the early 1950s, the Cold War belligerents began to compete for the allegiance of the newly independent states in former colonial areas. Many of the newly independent nations, however, had from the outset preferred not to choose sides in the Soviet-American struggle, wishing to be independent to follow their own path and aligned to neither of the Cold War antagonists.

This paper discusses the attempt of the newly independent Republic of Indonesia to pursue the policy of non-alignment during the early Cold War period, focusing on the Hatta, Natsir and Sukiman cabinets, 1950-1952. The central theme is the interplay between the Indonesian policy of non-alignment in the Cold War and the American policy of containing communism. Scholarly works which dealt with the subject of Asian non-alignment tended to focus on India, almost to the exclusion of other Asian neutralist states. It cannot be assumed that because both India and Indonesia had been non-aligned in the Cold War, their policies had been the same or that the American policies toward the two countries had been similar. The circumstances affecting the two countries have been rather different. An examination of the challenges from the United States toward the Indonesian attempt to pursue non-alignment would help to elucidate upon the nature of the Cold War in Southeast Asia. As Indonesian material in English on the topic is scanty, this paper makes extensive use of American documents but mined for information on Indonesia.

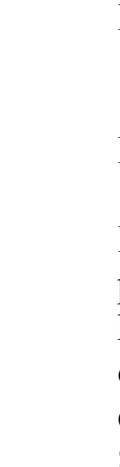

\section{Indonesia's Foreign Policy of 'independence.'}

Indonesia's policy of non-alignment in the Cold War originated during the revolutionary period while fighting for independence from the Dutch. It was later more popularly known as 'non-bloc' policy but during the early half of 1950s, it was labelled the policy of 'independence.' It was first enunciated by Vice-President Mohammad Hatta, then concurrently the Prime Minister of the revolutionary republic, in a speech in early September 1948 before the Central Indonesian National Committee. The backdrop for the speech was the mounting demands by left-wing Indonesian political parties for the abrogation of the Renville Agreement, termination of negotiation with the Dutch, and an alignment with the Soviet Union to offset the discernably pro-Dutch disposition of the United States in the Dutch-Indonesian conflict. This agitation later gave way to the abortive communist revolt in eastern Java in September 1948. In his speech, Hatta argued that in fighting for its freedom, Indonesia should not be cowed into choosing either being pro-Russian or pro-American; instead, Indonesia should determine its own standpoint and pursue its own goals. ${ }^{1}$ 
The issue of alliances and alignment in foreign relations is of course inextricably intertwined with the idea of national sovereignty and the exercise of national independence and is relevant only in the context of a conflict which impinged upon the interests of the affected state. In the case of Indonesia during the early Cold War, the choice for non-alignment was also borne in part from a basic distrust of the belligerent Cold War powers. Indeed, the Indonesian leadership generally distrusted both the Soviet Union and the United States. Despite their lack of direct evidence, Indonesian leaders suspected that the abortive communist revolt in Eastern Java in 1948 was Soviet-directed; and it was perhaps for this reason that Indonesia did not formalise mutual diplomatic recognition with the Soviet Union until late 1954. Distrust of the Soviet Union did not, however, lead the Indonesians to side unequivocally with the United States. While grateful to the United States for support in their struggle for independence, the Indonesians remained suspicious of the United States. Throughout the Indonesians' struggle against the Dutch, the United States had consistently supported the Dutch; not until it became clear that Dutch intransigence was threatening America's own interests both in Indonesia and Europe did the United States finally throw its weight on the side of Indonesia. Even then, during the negotiations at the Round Table Conference in late 1949, it seemed to the Indonesians that the United States had taken the side of the Dutch on the matter of the debts to be assumed by the Republic and, more importantly, on the issue of Irian Jaya, which remained under Dutch control. ${ }^{2}$

As the Cold War in Asia deepened during the post-revolutionary period, Indonesian leaders believed that a policy of 'neutralism' would safeguard Indonesia from being used aggressively by one bloc against the other. As Hatta explained it, "Indonesia plays no favourites between the opposed blocs and follow its own path through the various international problems." Since Indonesia did not share a common boundary with any of the Cold War belligerents, there was no pressing need to choose between the two blocs. "Her independent policy keeps her from enmity with either party, preserves her from the damage to her own interests that would follow from taking sides, and permits her to be friends with all nations on the basis of mutual respect." Indonesia was prepared to receive intellectual, material and moral assistance from any other country, "provided there is no lessening of, or threat to, her independence and sovereignty." A non-aligned foreign policy would also cater to domestic requirement: "Internal consolidation is the primary task. The government must show evidence of economic and social betterment if it is to offset the influence and agitation by radical circles. A foreign policy that aligned the country with either of the Great Powers would render this internal task infinitely more difficult."

Despite this profession of non-alignment, however, the international orientation of Indonesia during the first half of the 1950s was in fact considerably closer to the Western bloc than to the Sino-Soviet bloc. Shared belief in democratic institutions presumably played some part in this disposition for Indonesia regarded its ability to operate according to Western democratic standards as a mark of achievement and modernity. More important, Indonesian leaders recognised that Indonesia was "geographically situated within the Anglo-American economic and military orbit." ${ }^{4}$ Until the latter half of the 
1950s, Indonesia's trade and commerce were almost exclusively with Western bloc countries. Indonesians looked to Europe and the United States as their most significant sources of imports, their most important markets, and their primary sources of technical, economic and military assistance. Indonesian leaders were keenly aware that only the West, especially the United States, was in any position to offer economic and military assistance at that time. In addition, the Indonesians believed that the outcome of their claim to Irian Jaya depended on the attitude of the United States. Indonesian leaders were well aware how dependent Holland was on the United States and they were convinced that just a word from Washington would force the Dutch to relinquish control over Irian. Thus, although Indonesia professed to pursue a neutral and independent policy in the Cold War, it leaned discernibly toward the United States.

It is telling indeed that immediately after the transfer of sovereignty, the Hatta government proceeded to establish an embassy in Washington whereas exchange of diplomatic representatives with the Soviet Union was postponed until September 1954. Similarly, although Indonesia and the Peoples' Republic of China had mutually recognised each other in March 1950, Indonesia set up only a consulate in Beijing while the PRC established a full embassy in Jakarta. Quite apart from the expectation of American support for Indonesia's economic and territorial ambitions, these discrepancies also reflected the Indonesians' distrust of the communist powers in consequence of the Madiun affair, sustained during the immediate post-revolutionary years by open Chinese support for revolutionary communist tactics in Indonesia. When diplomatic relations with the Sino-Soviet bloc were stepped up during the mid-1950s, this was the result of a convergence of developments, both domestic and external, affecting both Indonesia and the Communist powers. Following the death of Stalin in 1953, the Sino-Soviet bloc shifted strategy toward an accommodation with non-aligned countries, a strategy to which Indonesia responded positively to counter-balance the influence of the United States.

\section{Challenges: American Cold War Policies}

Early challenges to Indonesia's stance of non-alignment in the Cold War had come mainly from the United States. By early 1949, Washington was persuaded that Southeast Asia was the "target of a co-ordinated offensive directed by the Kremlin." The establishment of a Soviet Embassy in Bangkok and especially the outbreak of "leftist" uprisings in Burma, Malaya and Indonesia, which shortly followed the Southeast Asia Youth Conference at Calcutta in February 1948, were taken as evidences of the Kremlin's "more direct" interest in Southeast Asia than had existed before. Washington believed that the Kremlin was seeking "ultimate control over SEA [Southeast Asia] as a pawn in the struggle between the Soviet World and the Free World." Southeast Asia was important to the Free World as a source of raw materials, including rubber, tin and petroleum and as a crossroads in east-west and north-south global communications. The National Security Council estimated that in seeking to gain control of Southeast Asia, the Kremlin was "motivated in part by a desire to acquire SEA's resources and 
communication lines but its immediate and perhaps even greater desire [was] to deny them to us." American policy-makers regarded Southeast Asia as vital to the security of the United States and its potential loss as damaging to the American position in the Far East. $^{5}$ A series of American diplomatic, economic and military survey missions sent to Southeast Asia between late 1949 and mid-1950 all emphasized the importance of Southeast Asia and argued for greater American commitment to check the spread of Communism to the region.

The United States' policy toward post-revolutionary Indonesia was of course much more dynamic than merely denying the archipelago to the communist. Indeed, a principal objective of United States' policy was to bring Indonesia into a full alignment with the Western powers in the deepening Cold War. As Assistant Secretary Walton Butterworth put it in a memorandum in October 1950 to Secretary Acheson: "As Communist gains on the Asiatic mainland increase, the importance of keeping Indonesia in the antiCommunist camp is of greater and greater importance. It is indeed the hope of the [State] Department that should the mainland be lost through Communism, Indonesia might provide a base of operations from which anti-Communist forces in Asia could begin recovery of the mainland." NSC 48, a State Department position paper on Southeast Asia, approved by the President in December 1949, stated US objectives in Indonesia thus:

In Indonesia, the United States should seek to strengthen the non-Communist political orientation of the government, promote the economic development of Indonesia and influence Indonesia toward greater participation in measures which support the security of the area and Indonesia solidarity with the free world. $^{7}$

To cultivate the pro-western leadership of the Indonesian republic and to ensure that they retained power, the United States undertook to provide the new republic with desperately needed economic, technical, and military assistances. Immediately after the conclusion of the Hague Agreement in November 1949, ECA provided Indonesia with $\$ 40$ million in grant aid, which was used primarily to purchase rice and textile. On January 9, 1950 President Truman approved the provision of $\$ 5$ million in military assistance to the Indonesian constabulary to maintain internal security "against Communist encroachment." ${ }^{\prime 8}$ The following month the Export-Import Bank agreed to lend Indonesia $\$ 100$ million to help finance the purchase of capital goods from the United States to reconstruct the Indonesian economy. ${ }^{9}$ In April the Griffin economic survey mission recommended immediate despatch of $\$ 14.5$ million in emergency aid covering several economic sectors as well as health and education under the Point IV Program. "[D]isinterested aid" by the West would make a "favourable political impression on government and people still suspicious [of] Western motives and will increase popular support [to the] government friendly [to the] US."

Indonesian leaders were appreciative of these American assistances to be sure, but they were particularly wary of any strings that might be attached to them. In a conversation 
with Ambassadors Phillip Jessup and Merle Cochran in Jakarta in early February 1950, President Sukarno frankly told that although American aid would be gratefully received he "felt that it must be tendered without strings" and that the United States must not "over-administer" the aid. When Jessup explained the 'administration' of ECA aid to Europe and that the US Congress required accounting, Sukarno countered that the situation in Asia was not comparable to that in Europe; that in Asia, the United States was dealing with sensitive 'new' countries who resented any implication that the United States was directing or supervising the use of aid which the United States might furnish. Sukarno "referred to America as the mother and the new Asiatic countries as grown sons who looked to their mother with affection and understanding but who did not wish her to interfere with the running of their own lives." Sukarno repeated this point several times during the course of the conversation and in later conversations with Ambassador

Cochran, emphasizing the "absolute necessity" for the United States to understand "the psychological nature of this problem in the new countries of Asia."11

Sukarno was understandably wary that the American aids would impinge upon Indonesia's stance of non-alignment which, indeed, was the exercise of independence in foreign policy. But if Indonesia was determined to hold aloof from the Soviet-American antagonism, the United States was equally bent upon co-opting Indonesia into its side in the Cold War. American officials held that a policy of neutralism and non-alignment was naive, self-deceptive and even dangerous. That Indonesian non-alignment was in fact pro-Western was apparently not good enough for the Cold War was an uncompromisable situation. The history of US-Indonesian relations during the early 1950s depicted the American attempt to co-opt and coerce Indonesia to abandon non-alignment and to enter into an active alliance with the United States in the Cold War.

\section{The Hatta Cabinet}

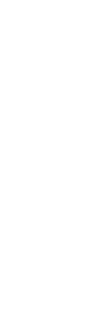

An early acute pressure on Indonesia to compromise its stance on non-alignment arose over the Indochinese issue, which came to a head in mid-1950. Despite the ideological leaning of the Vietminh, the Indonesian political leadership generally felt strong sympathy toward the Vietminh regime under Ho Chi Minh. They believed that the Vietminh enjoyed the support of the great majority of the Vietnamese and regarded its struggle against the French akin to their own revolution against the Dutch. Conversely, they regarded the French-supported Emperor Bao Dai a puppet, devoid of popular support and a mere ploy to perpetuate French colonialism in Indochina, reminiscent of the Dutch-sponsored federal states in Indonesia. The United States, however, after having itself recognised the Bao Dai regime, pressed Indonesia and other Southeast Asian countries to follow suit, which the Hatta cabinet refused to do. To coerce Indonesia into compliance the State Department delayed approving the recently promised $\$ 100$ million Export-Import Bank loan. Indonesian resentment against the United States was widespread. ${ }^{12}$ 
The American pressure had nearly backfired. In early April 1951, Sakirman, parliamentary leader of the Communist-line Partai Sosialis, submitted a motion urging the government to "enter into diplomatic relations with the Democratic Republic of Vietnam." Riding the wave of anti-American sentiment, the motion picked up considerable support among both Communist and non-Communist groups and, had it not been for the parliamentary skill of Mohammad Natsir, leader of the Masjumi party, might have carried in parliament. As voting on the Sakirman motion was about to take place, Natsir submitted a counter-motion, urging investigation of the situation in Vietnam prior to recognising it, in order to determine what the Indonesian government could do in concrete terms to advance the achievement of the national aspirations of the people of Vietnam. The Natsir counter-motion was carried in parliament by a vote of 49 to 38, with a majority of parliamentarians abstaining. After the vote, Hatta made clear to Parliament that the Government did not yet intend to recognise either Ho Chi Minh or Bao Dai, intending thereby to stay clear of the Vietnam issue in the Cold War. ${ }^{13}$

Ambassador Cochran was much relieved by the outcome of the vote. He cabled the State Department to speed up processing the promised $\$ 100$ million Export-Import loan, expressing his anxiety that the United States might lose the friendship of Indonesia "if after having made financial commitments we falter to such an extent that moderate government which we have considered [to be the] hope of new nation is embarrassed and perhaps defeated by our default." The State Department, for its part, was "satisfied with manner in which [the Indonesian Government] has so far handled [the] question [of the] recognition [of] Ho Chi Minh" and believed that "present Gov't will not take further step looking toward recognition [of] Ho regime for [the] foreseeable future." The State Department surmised that while Indonesia, "at present, do not wish become involved in cold war on our side they are far more unwilling to become involved on other side which would, of course, be result of their recognition of Ho." 15

Indonesia and the United States also differed in their respective attitudes toward the Peoples' Republic of China. The United States had refused to recognise the PRC. As Cochran explained it to Sukarno: "We felt [that the] communization of China came as directly from Moscow as if tremendous army of Muscovites had marched into China to install their institutions at point of sword....We did not feel Communism had been voluntarily adopted by the country and we doubted China would become irretrievably Communist. We did not risk believing, however, that Communism as it now exists in China is different from Communism as found in Moscow." In addition, the Beijing regime had "not conducted itself as a government of sovereign state duly cognizant of rights of other sovereign states and following accepted methods and standards in international intercourse."16

Most of the Indonesian leaders, on the other hand, were convinced that Mao Zedong's government enjoyed the support of the overwhelming majority of the Chinese people, that the cause of Jiang Jieshi's Nationalist regime on the mainland was lost, and that the communists were there to stay. Thus, although it was in no a hurry to open diplomatic relations with Beijing, the Hatta government promptly reciprocated when Beijing recognised Indonesia. In August 1950, the PRC dispatched an ambassador to Indonesia 
but it was not until early 1951 that the Indonesian government set up a consulate in Beijing. After its admission into the United Nations, the Indonesian government, working closely with other neutralist Asian governments such as India and Burma, made clear its belief that the representative of the Beijing government should replace those of the Chinese Nationalist government in the United Nations. ${ }^{17}$

Ambassador Cochran was disappointed when Indonesia decided to open diplomatic relation with the PRC. Shortly after the arrival of the Chinese ambassador in Jakarta, Cochran warned Sukarno against being complacent toward the Communists and of the dangers inherent in the Indonesian move in recognising the PRC.
I told Sukarno he and his people were inclined to become too self-satisfied and complacent over their newly-acquired sovereignty....I said they might lose everything in brief period unless they were keenly alive to dangers of Communist infiltration in their schools, labor organizations, army, etc. I told him to be sure not to under-rate recently arrived Chinese Communist Ambassador who now has large staff already here.... His government would have to be most vigilant in watching Chinese activities which can be covered up so easily in a colony of two million Chinese in this archipelago. ${ }^{18}$

More revealing of the dynamics in the interplay between the United States' Cold War policies and Indonesia's non-alignment was Washington's and Jakarta's differing reactions to the Korean War. Immediately after the war began, the Indonesian Government issued a categorical statement that the hostilities in Korea was yet another Cold War issue between the United States and Russia in which Indonesia wished to have no part. It banned all foreign warships taking part in UN operations in Korea from refuelling, loading or being repaired in Indonesian ports. In a statement on July 27, the Indonesian Minister of Information indicated that since Indonesia was not then a member of the United Nations it had no obligation to follow the Security Council order on aid to Korea, and any vessel intending to call at Indonesian ports should submit a request to the Indonesian government which would base its reply on the comity of nations. ${ }^{19}$

The State Department was extremely piqued, and characterized the Indonesian action as "indefensible" and "wrong-headed." Cochran was instructed to represent with the Indonesian authorities that while the United States fully understood the necessity for a "new uncertain Indo Govt maintaining neutrality within limits for reasonable length of time," the Indonesian Government should understand "at this moment that in [the] struggle between USSR and [the] free world, Indonesian choice is not only unavoidable but has been made." Particularly at a time when the United States and the free world were straining to support the UN on the battlefield, Indonesian refusal to allow United Nations' ships port privileges in Indonesia would "be taken at worst as defection from $\mathrm{UN}$ and at best as aberration." Cochran was to make clear to the Indonesian government that any continuation of these tendencies would "create situations in Congress and with US public opinion which will force US govt to reconsider it assistance programs." 20 
Raising the matter with Sukarno, Cochran expressed his disappointment that Indonesia, which owed its birth so largely to the UN and was now awaiting admission into that body, had not come out publicly in support of the UN cause. He argued that the war in Korea had stemmed from Communist North Korean aggression, with important support from the Russians. In fighting in Korea, the United States was merely upholding its pledge to the United Nations and would continue to fight on behalf of the UN-created South Korean state. In view of the American move in sending the Seventh Fleet to the Formosa Straits, it was not clear if the PRC would dare attack Formosa and risk a full war with the United States. But if this happened, Indonesians "surely ought to realize more fully than ever that there is a concerted move on the part of the Communists stemming from Moscow to take over all of Asia including islands to the south." The Philippines and Indonesia would be extremely vulnerable "if [the] Chinese, with Moscow's support, took - Formosa, moved en masse over Indochina and Thailand and then threatened the two island republics, still weak from their birth struggles and from Communist internal machinations." Indonesians should realise that only "US force alone that can save Indonesia from Communism and that [Sukarno] should keep that in mind in his international relations." There was no place for a neutralist third path in the Cold War struggle. "I said I realized Indonesian leaders had some conceptions of a 'third force' comparable to those advanced in India. I thought time would prove, however, that one must take side one feels is right one in such division as that which now faces the world." ${ }^{21}$ Sukarno was presumably unimpressed by Cochran's presentation.

\section{Military Aid: Indonesia's Achilles' Heel}

While the Indonesian government was able to ward off American advances regarding recognition of the Bao Dai regime and a tacit alliance with the United States in the Korean War, it was susceptible to American pressure over military aid. Indonesia desperately needed military equipments with which to maintain internal security, and only the United States was in any position to offer Indonesia such aid at this time. Pursuant to the provision of the $\$ 5$ million in military assistance to the Indonesian police which President Truman approved on January 9, the State Department instructed Ambassador Cochran to negotiate a bilateral agreement with the Indonesian government, requiring an undertaking by Indonesia to observe an embargo on export of "war-potential materials" to any enemies of the United States. Hatta objected to a formal agreement, which would have to be ratified by the Indonesian Parliament, but was agreeable to an exchange of diplomatic notes. Hatta assured Cochran that Indonesia was "strongly sympathetic" to the American resolve to check "Communist imperialism," but explained that "any promise even to consult on control of export of war-potential materials would be extremely dangerous to Indonesia." He explained that purchasers of Indonesian warpotential products would be given quotations only for delivery in Indonesia and that the buyers would have to take title and responsibility in Indonesia. Hatta was convinced that in times of hostilities the United States would continue to dominate the seas and America's enemies would therefore have no access to Indonesian market. Hatta, nonetheless, offered to give a verbal undertaking that the Indonesian government would 
not export war-potential materials to intermediate countries for transmission to enemies of the United States. ${ }^{22}$

The exchange of notes and Hatta's secret verbal undertaking, solemnised on August 15, represented only a qualified success in the American effort to co-opt Indonesia to its side in the Cold War. The State Department would have much preferred a formal treaty but conceded, "under the pressure of necessity," to an exchange of notes. ${ }^{23}$ Cochran advised the State Department that Hatta had gone the possible limit in his undertaking with the United States and that any more formal and extensive undertaking would be used against Hatta and his cabinet; and that Hatta repeatedly insisted that the United States "should know that Indonesian policy, while officially 'neutral,' is in reality a policy against Russia and its satellites," and that Indonesia "did not intend to contribute resources to

- Russia which would increase the strength of that country and its satellites and produce force which might be used aggressively against Indonesia." The Indonesian premier, however, emphasised that "Indonesia must be cautious vis-à-vis Communism until stronger internally." 24

On the Indonesian side, the exchange of notes respecting military aid from the United States revealed a strategic weakness in the Indonesian garb of non-alignment in the Cold War. Through the exchange of notes, Indonesia had avoided what would otherwise have been an open military alignment with the United State. But even then, Indonesia had compromised its own stance on non-alignment. Indeed, Hatta's remarks to Cochran about Indonesia's real leaning belied Indonesia's claims to non-alignment both in sentiment and spirit.

\section{The Natsir Cabinet}

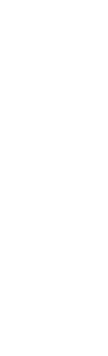

With the establishment of the unitary Republic of Indonesia in August 1950, Mohammad Natsir of the Masjumi party replaced Hatta as Prime Minster. Natsir and Mohammad Roem, the new Foreign Minister, were as sternly anti-Communist as Hatta but they were also especially sensitive to any charge of veering from the 'independent and active foreign policy.' Moreover, the Natsir coalition cabinet included parties strongly suspicious of the West. The new government had no problem in receiving economic aid from the United States and had in fact concluded such an agreement with the United States in October 1950. Military aid, however, was an entirely different matter. The cabinet was especially anxious to avoid any suggestion of committing Indonesia to an allied relationship with the West.

Shortly after assuming office, Roem informed Cochran that the government would receive the previously scheduled Melby-Erskine military survey mission for "an informal visit" but ruled out a military assistance program; his government desired to receive arms and military equipment only on a commercial and not on grant basis. This, Roem explained, "would be consistent with Indonesian foreign policy and would avoid domestic political difficulties. His government desired to be both independent and strong 
and he thought his people should be schooled in paying for what they need and making their own way." 25

When the Melby Mission arrived in Jakarta, Roem confirmed that the Indonesian government did not want to work through the Mutual Defence Military Program. He explained that "this meant no unfriendly attitude toward the United States" but that to obtain arms from the United States under the terms such as Hatta had negotiated on the police equipment "would not be in harmony with [a] foreign policy of independence and freedom of action." Indonesian acceptance of the Mutual Defence Agreement would be interpreted at once as Indonesia having taken sides. Furthermore, it would seriously endanger the life of the government. Roem pointed out that the principal leaders in the Natsir government were men whom Cochran had known and worked with and that the ambassador should be convinced that they were not sympathetic to communism. Roem told Cochran to "let Indonesia develop its own national leadership and take responsibility to solve its problems, always with feeling they could turn to the [United States] as friend with common ideals." Cochran averred that while he was convinced of "the safe political philosophy of moderate leaders in present government" he was not sure they were "sufficiently sensitive to [the] growing danger of Communism" and feared that they might wait too long before taking action, by which time it might be too late. ${ }^{26}$ Reporting the failure of his mission in Indonesia, Melby wrote the State Department: "It is apparent that our visit here was premature for a military arrangement such as we proposed and that any thing further can be expected only when a more mature political basis and atmosphere have been developed. We did not find any evidence of a Communist predisposition though danger of its growth should not be overlooked."27

Indonesian rejection of the Mutual Defence arrangement certainly marked the triumph of Indonesian non-alignment over the enticement of American military aid. However, when Indonesia's reactions to the United States is compared with the reactions of Burma, another Asian proponent of non-alignment, the relative fragility of Indonesia's garb of non-alignment became apparent. Whereas Burma had refused to receive the visit of the Melby-Erskine on grounds that entertaining such visit would compromise Burmese neutralism, the Indonesian government had received the Melby mission for "an informal visit." In the event, the fragility of Indonesia's stance on non-alignment came undone during the course of development over the Korean War in the United Nations in consequence of the entry of China in the fray in November 1950.

While concerned about the expansion of the Korea War, Indonesian leaders tended to regard Chinese intervention as an understandable response to General Douglas MacArthur's drive northward to the Yalu, ignoring Beijing's repeated warnings. In the United Nations Indonesia joined the Arab and Asian countries in petitioning the PRC to halt at the 38th Parallel. That gratified the United States but when Indonesia joined three other Asian countries in abstaining from voting on the motion to discuss a resolution on the withdrawal of Communist Chinese troops from Korea, the United States took exception. Talking to Sukarno in December 1950, Cochran stressed that "Indonesia should realize [that the] Chinese move into Korea [was] part of [an] overall Soviet plan to 
control Asia and that resolute defense on [the] continent of Asia [was] vital if Indonesia itself was to be spared....Indonesia must be awake to and admit [the] danger of Communist movement southward and formulate its policies accordingly." Referring to the Indonesia's request to purchase arms from the United States and pointing to the pressure for American equipments from American allies participating in the Korean struggle and the consequent difficulty in making equipment available outside Mutual Defense Aid Program, Cochran expressed his hope that the Indonesian government would find acceptable some sort of arrangement only slightly modifying that which he had consummated with Hatta on civil police equipment. ${ }^{28}$

Sukarno was less than impressed with Cochran's argument. He explained that the position Indonesia had taken in the United Nations was one which it conscientiously felt - would best contribute to preventing a Third World War. ${ }^{29}$ Anxious to avoid steps likely to freeze China in an uncompromising position, Indonesia and like-minded nations in the United Nations believed that the Korean problem might be easier to resolve in the context of a general Far Eastern settlement, one which also covered the status of Taiwan and Chinese representation in the United Nations. This group of nations also refused to accept the American-sponsored thesis that China was the aggressor nation in Korea.

While these initial Indonesian actions were in keeping with the spirit of non-alignment Indonesia was fast retreating from that stance however. In the UN vote in late January 1951 on the American resolution branding China as an aggressor, Indonesia abstained, breaking ranks with India and Burma which voted against the resolution. ${ }^{30}$ Desirous of American aid but opposed to the American position in the Korean War, Indonesia took the middle path of abstention and hoped thereby not to antagonise the United States unduly. Such was the Indonesian dilemma of dependence. ${ }^{31}$

For their part, American officials were aghast with what appear to them to be apparent Indonesian indifference. For the moment, however, their attempts to push Indonesia to abandon non-alignment were met with frustrations. Against the background of the deteriorating military situation in Korea, the State Department began urgently to consider establishing of a military pact in Asia. In early February, Cochran raised with Roem the possibility of a Pacific Pact, embracing Indonesia, the United States, Australia and America's other Pacific allies. Roem pointed out that such an arrangement would not be consistent with Indonesia's foreign policy. In response to further questioning from Cochran, Roem indicated that Indonesia expected the United States to come to its defence in the event of Communist attack on its territory whether or not a formal security arrangement existed between the United States and Indonesia. ${ }^{32}$

Cochran was especially vexed by Roem's statement. In a cable of February 3, he advised the State Department that it was perhaps time to reconsider the United States' approach to Indonesia.

Believe this propitious time to bring Indonesians face the realities of the world situation. US aid should not be taken for granted no matter how close our 
friendship has been or may continue with Indonesia. Indonesia will not only itself become a problem but will contribute to the strengthening of the AsiaticArab bloc, thereby creating a much bigger problem, if we continue too gentle a policy with this country.

Cochran held that the Indonesians would be "more likely to appreciate the benefits of a pact [with the United States] if we make them realize at once that any further favors from the US must be requested and merited on its record of behavior as a sovereign nation sympathetic to the policies of the free world."

Cochran's State Department colleagues were immediately sympathetic toward the suggestion of getting tough with the Indonesians. This line of thinking had in fact been - gaining both momentum and adherents within the Department since the last quarter of $1950 .{ }^{34}$ Reviewing the record of Indonesian relations with the United States in the Cold War, William Lacy, Director of the Office of Philippine and Southeast Asian Affairs, lamented that "many Indonesians appear to believe that Indonesia has less to fear from Communism than from American efforts to combat Communism." Despite their pressing needs, the Indonesians had been extremely reluctant to accept American technicians and economic aid. Cognisant of the internal difficulties faced by the Indonesian government, the United States had pursued a policy of "patience and perseverance" but it was now "necessary [to] apply more pressure in order to make the Indonesian realize that friendship between nations must be a two-way relationship." ${ }^{35}$ In late February, Assistant Secretary Rusk informed the Indonesian ambassador in Washington that in view of increasing US defence expenditures, Congress was expected to review ECA programs critically. ${ }^{36}$

The State Department's move to curtail the assistance program to Indonesia was vigorously opposed by ECA however. Colonel Allen Griffin, now ECA Director for the Far East, angrily charged during a luncheon with Lacy that Cochran was providing Senator McCarthy with "excellent ammunition" by wanting the United States to "pull out of Indonesia, thereby turning the place over to the Communists." Cochran, Griffin continued, "had made an abysmal mess of American relations with Indonesia and now, by wanting to kick ECA out of the country and getting hard-boiled with the Indonesians in the matter of supporting the US in Korea, joining the Pacific Pact, and related matters, was making bad matters impossible." Griffin insisted that Ambassador Cochran had personal reasons for objecting to the ECA programs and that such a negative approach was not the most effective means of combating Communism and bringing the Indonesians to the American side. The State Department defended Ambassador Cochran's record in Indonesia and argued that the proposed curtailment of aid had nothing to do with the larger American strategy toward Indonesia. Rather, the Department's position was based on the fact that Indonesia's gold and dollar exchange position had improved so greatly during the past year that it no longer required grant aid to buy commodities or services from the United States. ${ }^{37}$ Eventually, the State Department and the ECA reached an agreement to continue the program at a reduced level of \$9.95 million for 1951 and \$10.4 million for 1952 . 


\section{The Pro-American Sukiman Cabinet}

The Natsir government resigned in late March 1951 as a result of a parliamentary impasse over a domestic issue and was replaced by a Masjumi-PNI coalition cabinet under the premiership of Sukiman Wiryosanjoyo of the Masjumi. Much to the gratification of Ambassador Cochran and the State Department, the new government proved to be much more congenial to American interests than had the preceding Hatta and Natsir cabinets. Indeed, the Sukiman government pursued repressive anti-Communist measures domestically while adopting a foreign policy which closely identified with that of the United States. The extent to which Indonesia had veered away from non-alignment appeared especially starkly when Indonesia's policies are compared with that of Burma and India, two other prominent Asian neutralist states. In fact, during the tenure of the

- Sukiman government, Indonesia broke ranks with India and Burma on many important Cold War issues. The Sukiman government's decision to accept American military aid under the terms of the Mutual Security Act in early 1952, in effect consummating an alliance with the United States, belied its claims to neutrality in the Cold War.

The Sukiman government's initial response to the American request for a United Nations embargo on the shipment of strategic war materials to China betrayed little of its later pro-American tendencies. Indonesia was then enjoying the 'Korean boom' in rubber and tin and, naturally enough, there were serious misgivings over the wisdom of the embargo resolution. In addition, there was strong suspicion in Jakarta that the real American motive in introducing the embargo motion was to make the United States a single-buyer vis-à-vis the producing countries, so that it could push down the price of these raw materials. The PRC, for its part, had not been slow in playing the rubber issue. Soon after the Sukiman cabinet assumed office, the Chinese Embassy in Jakarta proposed a barter agreement whereby Indonesia would exchange rubber for rice. It was with this background that Foreign Minister Ahmad Subardjo, in reaction to critical questioning from the press, reportedly blurted on May 7 that Indonesia would "sell to the devil if it would serve the people's interests." "38 This hasty statement was immediately revoked, however. The Indonesian Embassy in Washington explained that Subardjo's statement was made off-the-cuff and was meant entirely for domestic consumption. ${ }^{39}$

The State Department was anxious that Indonesia observed the proposed UN embargo. Should Indonesia sell rubber to China, the effectiveness of the British embargo on selling rubber from its colonies to China would be destroyed. Moreover, historically, Indonesia had no trade with China; and for Indonesia to change the pattern of distribution of its produce particularly when the United States was attempting to organise the free world against Chinese aggression in Korea would be highly delinquent. ${ }^{40}$ In separate conversations with the Indonesian ambassador in Washington in mid-May, Assistant Secretary Rusk and Secretary Acheson told Ambassador Ali emphatically that should the attitude expressed by Subardjo became official policy, Indonesia could expect strong reactions from the United States, particularly in terms of American aids. ${ }^{41}$ 
Counting on continued American economic and technical aid and, perhaps more importantly, hopeful of procuring arms on a reimbursable basis from the United States, ${ }^{42}$ the Sukiman government succumbed to this American pressure. Whereas India and Burma voted against the United Nations' resolution placing an embargo of supplies of strategic raw materials to China, Indonesia abstained. Following strong American demarches in Jakarta, Washington and New York, Indonesia reluctantly complied with the UN embargo.

The Sukiman government managed, however, to exact a small 'fee' for its compliance with the UN embargo. Pointing to the difficult internal political situation and strong objections by the press and parliamentarians to Indonesian subscription to the embargo, Subardjo sought to obtain an additional \$50 million ECA loan to offset the estimated $\$ 150$ million in losses Indonesia would incur by complying with the embargo. Cochran, disgusted, bluntly told Subardjo that the Indonesian Foreign Ministry itself had been directly responsible for stirring up this opposition. He adamantly refused to recommend any additional loan, pointing out that Indonesia had yet to make full use of past loans. ${ }^{43}$

In mid-September, despite Cochran's continued but weakened opposition, the ECA agreed to provide Indonesia the additional $\$ 50$ million loan. Presumably, the State Department calculated that the loan was a small price to pay for Indonesian agreement to observe the embargo. By that time, moreover, much to the satisfaction of Ambassador Cochran and the State Department, the Sukiman government had taken several antiCommunist measures domestically. In July it refused admission to sixteen Chinese diplomats although they all had been issued entry visa by the Indonesian consulate in Beijing. The Indonesian Foreign Ministry charged that this was the third time the Chinese had violated 'diplomatic courtesy' by failing to give adequate 'prior notification' of the arrival of new embassy personnel. The real reason behind this move was to restrict the activities and contain the influence of the Chinese embassy among the Indonesian Chinese community. ${ }^{44}$ Perhaps even more gratifying to the United States were the antiCommunist raids of August 1951. On the basis of an alleged Communist plot to overthrow the government, the Sukiman government launched a series of massive arrests. Some fifteen thousand persons were arrested, prominently PKI and 'leftist' leaders, several hundred resident Chinese, and the cabinet's other political enemies. In the end, however, the government was unable to convince parliament that any real threat to the state had existed and, eventually, it was forced to release those arrested. ${ }^{45}$

On September 8, Indonesia signed the Japanese Peace Treaty, again breaking ranks with India and Burma, both of whom had boycotted the San Francisco Conference because the treaty was of American making and was intended as the cornerstone of the American Cold War policy in Asia. The Sukiman government explained that if Indonesia were to emulate India in concluding a separate bilateral peace treaty with Japan, "the atmosphere of good will would certainly be absent and Indonesia would certainly not be able to count on any support from the United States." ${ }^{46}$ In other words, the Sukiman cabinet was trimming its sails to catch the American dollars. After Indonesia signed the Japanese Treaty, the State Department agreed to provide the $\$ 50$ million loan which Subardjo 
requested. The Indonesian press was especially critical of such 'prostitution' and due to strong domestic dissent the Japanese treaty was not submitted to parliament for ratification until $1958 .^{47}$

\section{The Secret Cochran-Subardjo Agreement}

The Sukiman government's active anti-communism and pro-American leanings heartened Ambassador Cochran to attempt getting Indonesia to abandon its policy of non-alignment and enter a formal alliance with the United States. In January 1952, he succeeded in inducing Subardjo to sign the Mutual Security Act Agreement on terms which clearly implied Indonesian military commitment to the United States. Under the Mutual Security Act of October 1951, a state receiving grant military aid was required to subscribe to Article 511(a), which committed it to contribute fully "to the defensive strength of the free world." A state receiving reimbursable military aid or only economic and technical aid had merely to pledge, under Article 511(b), to "maintaining world peace and to take such actions as may be mutually agreed upon to eliminate causes of international tension." Since the unexpended balance for the Indonesian constabulary program, amounting some $\$ 3$ million, had been consolidated with the funds authorised by the Act, Indonesia was required to pledge under the 511(a) assurances if it elected to continue with the program on a grant basis. On the other hand, if Indonesia was prepared to place the constabulary program on a reimbursable basis, assurance based on 511(b) would suffice. $^{48}$

- The State Department expressively instructed Cochran to urge the Indonesian government to accept 511(b) assurances if he was satisfied that 511(a) was unacceptable, but Cochran advised the State Department that he would endeavour to persuade Indonesia to accept the more binding pledge under 511(a) rather that 511(b), arguing that "particularly bad impression would be created" if Indonesia was now obliged to commence paying for the balance of the long promised constabulary equipment. ${ }^{49} \mathrm{His}$ real motive was to bring Indonesia squarely into the American camp. Cochran thought the time right for such a move since a rightist cabinet was then in power. Moreover, Indonesia desperately needed and wanted American military equipment. Cochran believed the Indonesians, having been frustrated in their attempts to procure arms on reimbursable basis from West European countries and the United States, were ready to accept the American terms.

On January 5, 1952, Cochran and Subardjo signed the Mutual Security Assistance Treaty incorporating a somewhat watered-down version of 511(a) assurances. Subardjo, evidently, agreed to the provision because he was convinced that only through such an agreement could Indonesia procure desperately needed military equipment. ${ }^{50}$ In concluding the agreement, however, Subardjo did not consult his cabinet colleagues. Prime Minister Sukiman was informed of the negotiations but neither the Minister of Defence nor any member of the armed forces high command was consulted.$^{51}$ Evidently, when Subardjo informed the Prime Minister of the terms, Sukiman recognised that the 
expression "free world" would cause serious problem with the press and parliament. $\mathrm{He}$ asked that this be changed to "peace-loving world," but Cochran refused to alter the language of the agreement. Cochran later explained to the State Department that although he recognised the risk being taken in the inclusion of the phrase 'free world,' he thought it worthwhile to make this attempt to draw Indonesia one step closer to the free world and prevent back-sliding to the level of Burma. ${ }^{52}$ Despite some reservations, Subardjo nevertheless signed the agreement.

The State Department was jubilant and Cochran was highly commended for managing to persuade the Indonesian Government "to take additional step toward alignment with the West." 53 But this sense of diplomatic victory was short-lived. One month after the agreement was signed, the secret became public. The Indonesian Minister of Defence was apparently shocked when, on February 4, American military personals from the embassy in Jakarta approached him on putting the agreement into effect. The secret CochranSubardjo agreement was publicized in the Jakarta press, and over the next three weeks a flood of criticism descended upon the cabinet. Subardjo was attacked both for conducting secret diplomacy and on the contents of the agreement. The Indonesian press became even more indignant when it learned that Burma and India had also secured American economic aid under the MSA without having to subscribe to Article 511(a). Vilification of the United States, and particularly of Cochran's persistent attempts to coerce Indonesia into the American side in the Cold War, was widespread. American prestige ebbed very low.

The Indonesian cabinet met to discuss the matter on February 8 . It particularly objected to the implication of Indonesia's military commitment to the United States. Subardjo was instructed to make every effort to persuade Cochran to accept a post-factum change from 511(a) assurances to 511(b), but Cochran was adamantly opposed to "retracting from an agreement honorably entered." Instead, he advised the State Department that if Indonesia repudiated Subardjo's undertaking, the United States should immediately cease all form of aid to Indonesia. The policy interests of the United States, he argued, would best be served by impressing upon the Indonesians that "we are not engaged in world-wide give away program, but on [the] contrary, we are endeavouring first and most urgently to help those countries which are allied with us against mutually recognized common danger and, secondly to aid those under-developed countries which, because of unfavorable balance of payment, can not pay for needed capital equipment or technical assistance." Indonesia fell into neither category and was unwilling to assume the responsibility, which, by act of Congress, the United States was required to place upon it in order to receive the type of MSA aid Indonesia really needed. ${ }^{54}$

Cochran remained unmoved even when the Sukiman cabinet resigned in late February. Indeed, he was almost intransigent when the State Department instructed him to ensure that the Indonesian government understood that it could opt for 511(b) assurances in order to receive economic aid, protesting that he "could not believe" that the Department would "risk such humiliation" and asked for a reconsideration of the instruction. ${ }^{55}$ The State Department initially yielded to Cochran but eventually decided that the ambassador 
was misconstruing the antagonisms that had arisen between him and the Indonesian government as a basic antagonism between the Indonesian government and the United States government on the issue of the continuation of an economic assistance program. ${ }^{56}$ In July, the State Department sent Stanley Andrews, Director of the newly established Technical Co-operation Agency, to Jakarta to explain to the Indonesian government the transfer of US assistance for Asian countries from the Mutual Security Agency to the Technical Co-operation Agency, thereby removing the contagious issue of aid away from the ambit of the Cold War.

\section{Conclusion}

- Non-alignment in the Cold War, or the 'non-bloc' policy as it was later called, was an ideal in Indonesian foreign policy; and it remained essentially that, an ideal. In its attempt to pursue non-alignment Indonesia faced many critical challenges. In the main, this came from the Cold War policies of the United States. American official held that the policy of neutralism and non-alignment was naive, self-deceptive, indifferent, and even dangerous. That Indonesia's non-alignment in fact leaned toward the West was not good enough for the Cold war was an uncompromisable situation. The history US-Indonesian relations during the early 1950s had essentially been the dynamics of the United States' attempts to co-opt and coerce Indonesia into a full-fledge alliance with it and Indonesia's resistance thereto.

In retrospect, Indonesia's preference for non-alignment perhaps had slim chance for real success. Indonesia falls within the Anglo-American economic and military orbit. Indonesia looked to Europe and the United States as their most important sources of imports and markets, and their primary sources of technical, economic and military assistances. Indonesian leaders were keenly aware that only the West, especially the United States, was in any position to offer these aids at that time. Desirous of American aid, Indonesia invariably compromised its stance on non-alignment. Therein lay the main weakness in the Indonesians' pursuit of non-alignment. Unless Indonesia had viable and sustained alternatives to these Western sources, Indonesia would have to abide by the calls of the West.

Military aid, which was then only available from the West, was apparently Indonesia's Achilles' heel, but when Ambassador Cochran attempted to exploit it there were unfortunate consequences. The MSA episode marked the breaking point in the capacity to compromise on Indonesia's non-aligned foreign policy. The moral of the MSA episode and the overall American efforts to woo and coerce Indonesia into the Western bloc was tersely summarized by the British Ambassador in Jakarta on an earlier occasion: "you can encourage and foster the latent Indonesian hostility toward Communism, but you cannot attempt to bounce them into Americanism without producing the very evil you most hoped to avoid." $" 57$ 
Indonesia, the Cold War and Non-Alignment:

Relations of the Early Indonesian Cabinets with the United States, 1950-52

\section{Endnotes}

*An earlier version of this paper was presented at the $21^{\text {st }}$ Conference of the International Association of Historians of Asia, Singapore, 22 ${ }^{\text {nd }}-25^{\text {th }}$ June 2010.

${ }^{1}$ Mohammad Hatta, Mendanjung Antara Dua Karang [Manoeuvring Between Two Cliffs] (Jakarta: Department of Information, 1951).

${ }^{2}$ The most comprehensive study of the United States' involvement in the Dutch-Indonesian conflict is Robert J. McMahon, Colonialism and the Cold War: The United States and the Struggle for Indonesian Independence, 1945-1949 (Ithaca: Cornell University Press, 1981). Also see Richard Mason, "The United States, the Cold War and the Nationalist Revolution, 19451950," Journal of Oriental Studies, Vol. XXX no. 1 \& 2 (1992), Special Issue: The Cold War and Beyond in Asia, ed., Priscilla Roberts, pp.60-75.

${ }^{3}$ Mohammad Hatta, "Indonesia's Foreign Policy," Foreign Affairs (April 1953). The citations are from the reprint in Mohammad Hatta, Portrait of a Patriot: Selected Writings of Mohammad Hatta (Singapore: Gunung Agung, 1981), pp. 550-551, 555.

- ${ }^{4}$ Sutan Sjahrir, Our Struggle (November 1945), translated by R..O. G. Anderson (Ithaca: Cornell University Modern Indonesia Project, 1968) p. 24. Sjahrir was the first Prime Minister of the Republic of Indonesia.

${ }^{5}$ NSC 51 "United States Policy Toward Southeast Asia," A Report to the National Security Council by the Secretary of State, March 29, 1949, NSC Files, Record Group 273, Modern Military Branch, National Archives, Washington D.C.

${ }^{6}$ Memorandum, Walton Butterworth to Secretary Acheson, October 21, 1950, Department of State Central Files, 890. 20/10. 2449, Confidential US State Department Central Files: The Far East Internal Affairs and Foreign Affairs, 1945-1959 (University Publications of America, 1991), The Far East,1945-49, reel 11.

- ${ }^{7}$ NSC 48/1, "The Position of the United States with Respect to Asia," December 23, 1949, in U.S Congress, House, Committee on Armed Services, United States-Vietnam Relations, 1945-1967: A Study Prepared by the Department of Defense (Washington, 1971), Book 8. pp. 226-272.

${ }^{8}$ Memorandum, Secretary of State to President Truman, January 9, 1950, Foreign Relations of the United States 1950, Vol. VI: East Asia and the Pacific. Washington D.C.: US Government Printing Office, 1976, p. 964. Hereafter, volumes in this series will be abbreviated FRUS, followed by the year.

${ }^{9}$ Telegram, Jessup to Deputy Under Secretary Rusk, February 3, 1950, Ibid., p. 978, footnote 2; Telegram, Rusk to Jessup, February 7, 1950, Ibid., p. 978; also see Telegram, Cochran to the Department of State, January 29, 1950, Ibid., pp. 973-975.

${ }^{10}$ Telegram, Griffin to the Secretary of State, April 22, 1950, Ibid., p. 1016 
${ }^{11}$ Memorandum of Conversation, February 3, 1950, FRUS 1950, VI, pp. 975-978. Memoranda by Jessup of conversations with other Indonesian leaders and American officials in Jakarta are filed in Department of State Central Files, 790.00/1-2450, Confidential US State Department Central Files: The Far East, 1950-1954, reel 2. Telegram, Cochran to the Department of State, March 23, 1950, FRUS 1950, VI., p. 990.

${ }^{12}$ George McTurnan Kahin, "Indonesian Politics and Nationalism" in Asian Nationalism and the West, ed., William Holland (New York: The Macmillan Company, 1953), p. 174.

Ibid., pp. 174-75; Information Office, Embassy of Indonesia, Washington, Report on Indonesia, Vol. 1 no. 46 (June 16, 1950) p. 1. Also see Christopher Goscha,"Choosing between the two Vietnams: 1950 and the Southeast Asian Shifts in the International System" in Christopher Goscha and Christian Ostermann (eds.), Connecting Histories: Decolonization and the Cold War in Southeast Asia, 1945-1962 (Woodrow Wilson Center Press and Stanford University Press, 2009) pp. 207-237.

${ }^{14}$ Telegram, Cochran to the Department of State, June 7, 1950, FRUS 1950, VI, pp. 1029, footnote 1 .

- ${ }^{15}$ Telegram, Secretary Acheson to Cochran, June 16, 1950, Ibid., pp. 1029-1030.

${ }^{16}$ Telegram, Cochran to the Department of State, August 26, 1950, Ibid., p. 1054.

${ }^{17}$ Kahin, "Indonesian Politics and Nationalism," p. 172; David Mozingo, Chinese Policy toward Indonesia, 1949-1967 (Ithaca: Cornell University Press, 1976) pp. 86-90.

${ }^{18}$ Telegram, Cochran to the Department of State, August 26, 1950, FRUS 1950, VI., pp. 1054 -
1057.
${ }^{19}$ Telegram, Cochran to the Department of State, July 28, 1950, FRUS 1950, Vol. VI., p. 1040, footnote 1 .

- ${ }^{20}$ Telegram, Department of State to Cochran, July 26, 1950, Ibid., pp. 1039-1040; telegram, Cochran to the Department of State, July 28, 1950, Ibid., p. 1040, footnote 1. Italics in the quotation is mine.

${ }^{21}$ Telegram, Cochran to the Department of State, August 26, 1950, Ibid., pp. 1055-1057.

${ }^{22}$ Telegram, Department of State to Cochran, May 24, 1950, Ibid., pp. 1025-1027; telegram, Cochran to the Department of State, June 7, 1950, Ibid., pp. 1027-1029; telegram, Cochran to the Department of State, July 26, 1950, Ibid., pp. 1037-1039; telegram, Cochran to the Department of State, August 9, 1950, Ibid., pp. 1046-1050

${ }^{23}$ Telegram, Department of State to Cochran, August 12, 1950, Ibid., p. 1051 footnote 3.

${ }^{24}$ Telegram, Cochran to the Department of State, August 16, 1950, Ibid., pp. 1051-1052. 
Indonesia, the Cold War and Non-Alignment:

Relations of the Early Indonesian Cabinets with the United States, 1950-52

${ }^{25}$ Telegram, Cochran to the Department of State, September 30, 1950, Ibid., pp. 1069-1072.

${ }^{26}$ Telegram, Cochran to the Department of State, October 10, 1950, Ibid., pp. 1078-1080.

${ }^{27}$ Telegram, Melby to the Department of State, October 11, 1950, Ibid., ,p. 1080, footnote 2.

${ }^{28}$ Telegram, Cochran to the Department of State, December 8, 1950, Ibid., pp. 1096-1098.

${ }^{29}$ Ibid.

${ }^{30}$ For official view on the Indonesian position on the Chinese intervention in the Korean conflict, see Report on Indonesia, Vol. II, nos. 14-19. For discussion of Indonesian position in the United Nations, see among others, Lawrence S. Finkelstein, "Indonesia's Record in the United Nations,"

International Conciliation (November 1951) no. 474, pp. 526-533.

${ }^{31}$ For a discussion on this dilemma of dependence, see Franklin B. Weinstein, Indonesian Foreign Policy and the Dilemma of Dependence: From Sukarno to Soeharto (Ithaca: Cornell University Press, 1976).

- ${ }^{32}$ Telegram, Cochran to the Department of State, February 3, 1951, Foreign Relations of the United States 1951, Volume VI: Asia and the Pacific (Washington: US Government Printing Office, 1977) pp. 145-147.

${ }^{33}$ Ibid., p. 147

${ }^{34}$ Memorandum, Lacy to Assistant Secretary Rusk, September 5, 1951, Ibid., pp. 140-141.

${ }^{35}$ Memorandum, Lacy to the Assistant Secretary for Economic Affairs, February 15, 1951, Ibid., pp. 597-598; also see Telegram, Department of State to Cochran, February 15, 1951, Ibid., pp. 596-597.

${ }^{37}$

Telegram, Acting Secretary Webb to Cochran. February 24, 1951, Ibid., pp. 606-607.

On the controversy between the ECA and the State Department, see Memorandum of Conversation, February 15, 1951, Ibid., pp. 598-602; Telegram, Cochran to Department of State, February 17, 1951, Ibid., pp. 603-605; Memorandum, Rusk to Griffin, February 20, 1951, Ibid., pp. 605-606; Memorandum, Lacy to Rusk, March 19, 1951, Ibid., pp. 619-623; Memorandum of Conversation, March 20, 1951, Ibid., pp. 623-625.

${ }^{38}$ Kahin, "Indonesian Politics and Nationalism,” p. 177.

${ }^{39}$ Telegram, Department of State to Cochran, May 9, 1951, FRUS 1951, VI., pp. 647, footnote 2.

${ }^{40}$ Memorandum, Rusk to Secretary Acheson, May 14, 1951, Ibid., pp. 650-652.

${ }^{41}$ Telegram, Department of State to Cochran, May 11, 1951, Ibid., pp. 647-649; Telegram, Department of State to Cochran, May 14, 1951, Ibid., p. 653. 
${ }^{42}$ Telegram, Cochran to the Department of State, May 15, 1951, Ibid., p. 655, footnote 5.

${ }^{43}$ Telegram, Cochran to the Department of State, June 21, 1951, Ibid., pp. 681-682.

${ }^{44}$ Mozingo, Chinese Policy toward Indonesia, pp. 98-100.

45 Herbert Feith, The Decline of Constitutional Democracy in Indonesia (Ithaca: Cornell University Press, 1962) pp. 187-192.

${ }^{46}$ Ibid., p. 192

${ }^{47}$ Ibid., pp. 193-196.

- ${ }^{48}$ Telegram, Acting Secretary of State Webb to Cochran, November 23, 1951, FRUS 1951, VI pp. 729-733.

${ }^{49}$ Telegram, Cochran to the Department of State, December 11, Ibid., p. 749.

${ }^{50}$ Telegram, Cochran to the State Department, February 19, 1952, Foreign Relations of the United

- States 1952-1954, Volume XII: East Asia and the Pacific (Washington: US Government Printing Office, 1987) p. 268-269.

${ }^{51}$ For discussion on the Indonesian side of MSA Agreement, see Kahin, "Indonesian Politics and Nationalism," pp. 193-194; Feith, Decline of Constitutional Democracy, pp. 198-201.

52 Telegram, Ambassador Cochran to the Department of State, January 7, 1952, FRUS 1952-1954 pp. 246-248; Telegram, Ambassador Cochran to the Department of State, February 18, 1952, Ibid., pp. 266-267.

${ }^{53}$ Telegram, Department of State to Cochran, January 8, 1952, Ibid., p. 248.

Telegram, Cochran to the Department of State, February 18, 1952, Ibid., pp. 266-267; Telegram, Cochran to the Department of State, February 22, 1952, Ibid., pp. 271-274.

55 Telegram, Department of State to Cochran, February 22, 1952, Ibid., p. 274 footnote 1; Cochran to the Department of State, February 22, 1952, Ibid., pp. 274-275.

${ }^{56}$ Memorandum, Samuel T. Parelman, Special Assistant for Far Eastern Regional Program, to Assistant Secretary John Allison, June 20, 1952, Ibid., p. 249 footnote 1.

${ }^{57}$ Telegram, British Embassy, Jakarta, to the Foreign Office, February 16, 1951. FH1631/6. FO371/92510. National Archives, Kew, United Kingdom. 